\author{
Charles Chastain \\ (University of Arkansas, Little Rock)
}

Introduction

In August of 1983 Federal Judge G. Thomas Eisele of the Eastern District of Arkansas held that a person is entitled to a new trial if he/she is tried for a capital crime and convicted in a two-stage trial and those persons who could never vote for the death penalty are automatically excluded for participation in the guilt-innocence phase of the trial. ${ }^{1}$ In a long opinion, analyzing the various aspects of the "death-qualified jury" issue, Judge Eisele relied very heavily on social science data from psychologists to conclude that barring those opposed to the death penalty in any form from the guilt-innocence phase of a trial would have the effect of eliminating a "distinctive group" in the community and thus violate the right of the defendant to be tried by a jury drawn from a cross-section of the community (See Duren v. Missouri (1979). ${ }^{2}$

The Arkansas case, originally known as Grigsby v. Mabry, was upheld by the Eighth Circuit Court of Appeals in St. Louis. ${ }^{3}$ However, since it stood in The 4th Circuit reached the same conclusion as in Spinkellink in Keeton $v$. Garrison 742 F 2nd 124 (4th Cir., 1984).direct conflict with the case of Spinkellink v. Wainwright, ${ }^{4}$ decided by the Fifth Circuit Court of Appeals in New Orleans in 1978, it presented an issue ripe for a grant of certiorari by the U.S. Supreme Court, and the writ of certiorari granted led to a decision on the issue in the case of Lockhart v. McCree in May of 1986.

The issue of whether or not it is constitutionally permissible to exclude those who could never vote for the death penalty in any case from every phase of a capital trial is one of the latest issues to be settled in the long-lasting debate as to whether states will ever be able to impose the death penalty with the regularity which existed prior to the 1960 s. Had the Supreme Court come to agree with the Grigsby decision, states would have had a great deal more difficulty getting death penalties from juries than in the past.

The matter of uniquely qualifying jurors in death penalty cases first came before the Court in Witherspoon v. Illinois $(1968)^{5}$ when the Court held that it was constitutionally impermissible to eliminate a prospective juror who stated that he/she was generally opposed to the death penalty, but was willing to agree that he/she could vote an accused person guilty if the facts of the case warranted that decision. In other words, Witherspoon stands for the proposition that some persons may be excluded for cause in capital cases if they would not vote the death penalty regardless of the strength of the state's case against an individual, but others who have only a general opposition to the death penalty may not be excluded for cause. This analysis of the Witherspoon case seems adquately 
supported by the language of a footnote in that case stating that unless a venireman is "irrevocably committed, before the trial has begun, to vote against the penalty of death regardless of the facts and circumstances that might emerge in the course of the proceedings," he/she cannot be excluded. ${ }^{6}$

The Witherspoon case took on new meaning with the Furman v. Georgia ${ }^{7}$ and Gregg v. Georgia ${ }^{8}$ cases decided in the 1970s. In Furman the Court agreed that the death penalty violated the Constitution when applied discriminately, but intimated that it (the Court) would support the constitutionality of the death penalty if procedural flaws were remedied by eliminating various discretionary phases of the proceedings which led to discrimination against poor and minority defendants. The Gregg decision settled the issue clearly-the death penalty does not per se violate the Eighth Amendment if the penalty is properly arrived at, and the defendant is given adequate opportunity to have his case reviewed to eliminate any procedural failings. An important section of any state statute approved under the Furman-Gregg doctrine is that the death penalty decision be a separate decision from that of guilt or innocence.

The $\mathrm{McCree}$ case could not properly be categorized as a cruel and unusual punishment case. It must be compared to the Furman opinion stating that the death penalty can be unconstitutional if it is administered in such a way as to fall more heavily on some segments of our society than others. There are several significant questions to consider in looking at the $\mathrm{McCree}$ case. First, if it can be shown that persons who strongly support the death penalty are more likely to vote for conviction under any circumstances than those who strongly oppose it, would the exclusion of the latter be a fatal flaw to a process developed after and in conformity with the suggestions offered in Furman v. Georgia? Second, do those people who scould never under any circumstance support the death penalty constitute a "distinctive group within the community" and therefore make their exclusion a violation of the requirement that a jury be drawn from a cross-section of the community? Third, how far should the Court go in relying on social science data to determine constitutional issues? Fourth, is the right of opponents of the death penalty to serve in juries an inherent part of due process of law in the sense that the right to privacy is?

\section{The Cross Section Issue}

First one must look at the cross-section jury cases to determine their applicability to the $\mathrm{McCree}$ case. It should be noted at the outset that Judge Eisele based his decision on the principle that a "distinctive group in the community" could not be excluded and that strong opponents of the death penalty constituted a "distinctive group." Decisions by the Court on the crosssection issue have been of faily recent vintage and almost all of them have been resolved in the defendant's favor. In Swain v. Alabama $(1965)^{10}$ the Court considered the appeal of a black convicted by an all-white jury in a county where 
no blacks had ever served on a jury in a serious case. The Court held the particular arrangement in Alabama was the product of the peremptory challenge process and that process, because of its long history in the United States must be allowed to continue. The challenge process could be overturned if it was shown that the peremptory challenges were being used in a perverted manner. However, two years later in Hoyt $v$. Florida ${ }^{11}$ the Court rejected the argument by Florida that making women as eligible as men for jury service would so interfere with their "distinctive role in society" the state had ample jurisdiction for excluding them except on an affirmative request that they be allowed to serve. The Hoyt decision was buttressed by Carter v. Jury Commissioner (1970) ${ }^{12}$ when the Court held unconstitutional an Alabama law limiting jury duty to those persons who are "generally reputed to be honest and intelligent and esteemed in the community for their integrity, good character and sound judgement." In 1972 in Peters $v$. Kiff, ${ }^{13}$ the Court determined that the exclusion of black jurors was found to be following a pattern of discrimination. It agreed that a white defendant has standing to sue and is entitled to relief upon showing that blacks had been systematically excluded from the petit jury that convicted him.

The one case in this area where the Court was not sympathetic to the defendant is U.S. v. Hamling (1974). ${ }^{14}$ Hamling argued that having no twenty-totwenty-four-year-olds on the jury panel violated his fair trial rights in an obscenity case. The jury simply had not been redrawn in four years and therefore included no one under twenty-five. The Court denied Hamling's claim, but agreed that a defendant would have a constitutional claim in this process was allowed to occur regularly.

Two cases most pertinent to the argument of $\mathrm{McCree}$ that death penalty opponents constitute a "distinctive group" relate to the use of women as jurors. In Taylor v. Louisiana (1975) 15 the Court held that excluding women from jury service unless they had previously filed a written declaration of their desire to be on a jury, a requirement not imposed on men, was unconstitutional. And, as mentioned above, the Court held in Duren v. Missouri (1979) ${ }^{16}$ that the state of Missouri violated the constitution with its rule that allowed any women to be excused from jury duty who simply asked that she be excused. A controversy similar to the death-qualified juries issue came before the Supreme Court with Adams v. Texas ${ }^{17}$ in 1980. At issue in that case was the Texas practice of disqualifying jurors in capital cases unless the juror could agree that the possibility of the defendant receiving the death penalty would not affect his/her judgment. The Court held that the Texas scheme was too lenient in disqualifying jurors who should properly have been permitted to serve under the Witherspoon doctrine.

How do these cases relate to the $\mathrm{McCree}$ case? They are precedents for the principle, now accepted, that a defendant is entitled to have a jury which is drawn from a panel representative of a cross-section of the community and that any rule of procedure which automatically excludes (or makes it easy to exclude) a 
distinctive group within the community violates that requirement of crosssectionality.

\section{Scrupled Jurors as a Distinctive Group}

It would be helpful to the reader to look at the potential jurors in a death penalty case in the following categories: ${ }^{18}$

1. those persons who will always vote for the death penalty if given the opportunity.

2. those persons who support the death penalty but will vote for it only if the circumstances of the particular case warrant it.

3. those persons who oppose the death penalty generally but would be willing to vote for it under some circumstances if the state provided for it.

4. those persons who could never vote for the death penalty in a criminal case, no matter what evidence is presented.

A 1971 study by Jurow ${ }^{19}$ indicated that the above categories are represented in the following manner: category one, $2 \%$; category two, $5 \%$; category three, 20\%; category four, $10 \%$. In response to the Court's suggestion in Furman $v$. Georgia, states desiring to have the death penalty have established a two-stage trial system for capital cases. The first phase is aimed at hearing evidence to determine the guilt or innocence of the defendant and the second phase focused on the penalty to be given if the defendant was found guilty at the first phase. The ruling by Judge Eisele in the Grigsby-McCree decision is that to exclude those in category four above from the guilt-innocence phase of a capital case is to exclude from jury duty a "distinctive group" in the community and thereby violate the cross-section requirement as established in the cases beginning with Swain and culminating with Taylor and Duren. McCree's argument was that by excluding those in category four the state was automatically excluding everyone who holds the state to a high level of proof to get a conviction and including all those persons who would be most prone to vote guilty. ${ }^{20}$ Since this exclusion would not be permitted in an ordinary felony trial, so the argument goes, it follows that it violtates the defendant's right to a fair trial in argument in the Spinkellink case by saying that even though death qualified jurors (those in categories 1-3 above) may be prone to convict (relative to category four), to 
allow such people (category four) on juries in capital cases will tend to defeat a state's attempt to enforce the death penalty which the Supreme Court has upheld as constitutional.

One of the arguments made by the State of Arkansas in defending its practice of death qualified juries for capital cases in that all persons who fall into category one above area also excluded. In other words, if a prospective juror stated that he/she would vote for the death penalty regardless of the evidence presented in the case, then he/she would be excluded as lacking fairness and impartiality. The argument here is that, for example, if a person can be shown to be a racial bigot, he/she would be excluded from jury service in a case involving a black defendant or victim, even though to exclude al lracial bigots might in some jurisdictions be to exclude a significant proportion of the population. Arkansas argued that persons who come to a trial with their decision made prior to any evidence being presented should be excluded regardless of which side they may be on. Judge Eisele, in the Grigsby-McCree decision, rejected the state's formulation of the issue by balancing category one persons against category four persons with the statement that category one (automatic death penalty persons) would involve so few persons that to balance them against category four (absolutely against death penalty) will give the prosecutor significant advantage, because the prosecutor will lose very few persons who are guiltprone while the defense will lose a significant number of persons who are less conviction prone. $\mathrm{McCree}$, of course, did not argue that those absolutely opposed to the death penalty should be allowed to participate in the penalty phase of the trial of capital offenses.

The Arkansas Supreme Court also had occasion to look at the deathqualified 659 S.W. 2d 168 (1983).jury issue in Rector v. Arkansas, ${ }^{21}$ decided in October, 1983. That Court held that category four veniremen were not proper subjects for jury duty in capital cases, even at the guilt-innocence phase, because they could not be presumed to be impartial and conviction-proneness is not inherently wrong or destructive of impartiality. The Court noted its objection to the characterization of those supporting the death penalty as barbarians, and stated that a requirement that a person oppose the death penalty to be civilized would condemn most Americans. It further noted that the $\mathrm{McCree}$ decision favored the most heinous criminals over all other criminals and expressed the view that a jury system that has worked so well for so long ought not to be tweisted for the benefit of the worst of criminals.

Woodard v. Sargent, ${ }^{22}$ also decided by Judge Eisele on the same day he decided the $\mathrm{McCree}$ case, indicates that he did not intend to make easy a claim that the death-qualified process denied a defendant his/her rights to a fair trial. Woodard argued that the Witherspoon principle had been vilated when a prospective juror was removed for cause after he agreed that he could never vote for the death penalty in the case because he worked with the defendant's father. The judge held that this particular veniremen fell into category four above and the 
questions focused on the penalty phase of the trial and he was therefore properly removed.

As can be seen by the foregoing discussion, three fundamental questions to be answered are: (1) whether those persons in categories 1-3 above are more prone to vote guilty at the guilt-innocence phase of the trial, (2) how may this be determined, and (3) what effect should it have in determining the validity of the trial? The more exact question is how the courts go about balancing legal tradition against the findings of modern social science? A review of the relevant data indicates that social science (Psychology in this case) supports the proposition that persons who oppose the death penalty strongly (category four persons) are significantly less likely to vote guilty regarding any crime than other persons, particularly those who are strong supporters of the death penalty. ${ }^{23}$ Without considering the issue as to who is right or wrong in their beliefs regarding the death penalty, it is difficult to deny that including or excluding those strongly opposed to the death penalty would potentially affect the outcome of a case. On the other hand, there is a good deal of legal tradition supporting the practice of excluding category four persons. One could also argue that those persons who do support the death penalty, and in an ordinary case would tend to agree with the prosecutor more often than others, probably do hold the prosecutor to a higher level of proof when voting on the death penalty than they would if they were voting for ordinary punishment. ${ }^{24}$ In the Lockhart decision, the majority opinion expressed doubt about the studies presented by McCree. The court noted that only six of the fifteen studies relied on to prove the conviction - proneness of death penalty advocates actually dealt with that particular issue, and, of those six, three were considered and rejected as non-compelling by the court in the Witherspoon decision. As to the other three studies, the court noted that they were the results of experiments involving mock juries and not studies of juror behavior in real death penalty situations. Even if these studies were valid and supportive of McCree's claims, the majority held, that would not mean that the states violated due process by death-qualifying juries. Writing for the majority, Justice Rehnquist pointed out that 1) the cross-section requirement was never meant to apply to a particular petit jury, but only to potential jurors; 2) that, unlike persons excluded from jury duty because of their race or sex, deathqualified excludable jurors are excluded because of a characteristic they have the ability to change; and, 3) these excludables are permitted to serve on juries deciding cases not involving the death penalty. He rejected McCree's argument that the excludables should be permitted to serve at the guilt-innocence stage of a death penalty trial by asserting that a two-stage trial using two different juries would amount to having two trials over the same evidence. To Justice Rehnquist, the balancing of predispositions of individual jurors must be the product of the voir dire process for selecting jurors. 


\section{The Role of Social Science}

Eventually, the courts will have to ascertain how much social science data is permitted in criminal trials. After all, social science is heavily grounded in determinism, a concept which if accepted in the extreme would destroy the law and its foundation of free will. A good illustration of the dilemma posed by this social science-law dichotomy is the case of People $v$. Collins, ${ }^{25}$ decided by the California Supreme Court in 1968. In Collins, the prosecutor had introduced evidence through an expert witness that he claimed amounted to "proof beyond a statistical doubt" and therefore superior to "proof beyond a reasonable doubt". On appeal, the California Supreme Court, without looking into the methodological problems in the prosecutor's reasoning, ordered a new trial. They admonished the prosecutor that although proof beyond a statistical doubt, the latter was required in the American system of jurisprudence - to imply anything else would prejudice the jury. Further, in cases considering the extent to which an expert witness's testimony should affect the outcome of a criminal trial involving the defense of insanity, the courts have been careful to make sure that the expert witness's testimony be seen as mere evidence and not conclusionary to the point of superseding the jury's function. ${ }^{26}$

The U.S. Supreme Court ignored the findings of jury experts in Apodaca v.Oregon (1972) ${ }^{27}$ when it held that conviction need not be by a unanimous jury in ordinary felony cases. However, more recently the Court did accept socialscience data as significant in its decision in Ballew v. Georgia (1978), ${ }^{28}$ setting the minimum number of jurors at six in felony trials, and in Burch $v$. Louisiana $(1979)^{29}$ required a unanimous jury verdict in trials with only six jurors. Of course, the Court has allowed a good portion of social science data to be used in deciding cases dealing with areas of the Constitution other than criminal law and procedure, and one could justifiably say at this juncture that the issue of deciding how much social science data to allow is still very much determined by individual justices and is not established as yet in our legal tradition.

\section{Simple Due Process}

Finally, the Court could have chosen to deal with the issue of deathqualified juries as they have many other complicated issues by treating it as a "fair trial" issue, a "general due process" issue, or even as an issue for which there is not constitutional remedy but one which must be decided in light of practical considerations. For example, in Moore v. Dempsey $(1923)^{30}$ the Court held that, in order for an individual to get a fair trial, the atmosphere must be such that he/she has a chance to win, including the right to retain counsel if he/she could afford an attomey. Every student of constitutional law is familiar with the case of Rochin v. California $(1952)^{31}$ in which the Court held that police action 
which was "shocking to the conscience" violated the due process clause of the Fourteenth Amendment. Yet, on other occasions the Court has allowed the state great discretion in its treatment of persons, particularly when ideals conflicted with practical considerations. Those persons of Japanese ancestry living along the west coast during World War II know well ${ }^{32}$ the meaning of Chief Justice Hughes statement that the "Constitution is what the Supreme Court says it is."

\section{Conclusion}

In conclusion, one must recognize that the Supreme Court faced a serious dilemma when it agreed to grant certiorari in the $\mathrm{McCree}$ case. The Court had already held that the death penalty does not per se violate the Eighth and Fourteenth Amendments, but it had also agreed that the death penalty violates due process if it is unfairly administered and that due process is violated if a "distinctive group" in the community is denied access to the jury process. Social science data, although not conclusive, tend to indicate that death-qualifying of juries in capital cases does deny a "distinctive group" in the community access to the jury process. In deciding this issue the Court considered the question as to whether including those persons strongly opposed to the death penalty in capital cases, even at the guilt-innocence phase only, would undermine its decision in Gregg v. Georgia. Additionally, requiring different juries for the same trial to decide the guilt-innocence question and penalty question respectively, as would probably have been required by the lower court decision, would pose new questions about the fair trial issue which have never come before the Court up to this time. It is obvious that the $\mathrm{McCree}$ decision poses questions that reach to the very heart of our legal tradition. It also paved the way for decisions about new questions surrounding the death penalty such as whether social science data about the effect of the victim's race on death penalties, decided in April this year, ${ }^{33}$ and whether or not it is constitutionally permissible to executive someone who committed a crime while still a minor. ${ }^{34}$

\section{Endnotes}

${ }^{1}$ Grigsby v. Mabry, 569 F. Supp. 1273 (E.D. Ark. 1983).

${ }^{2} 489$ U.S. 357 (1979).

${ }^{3} 637$ F. 2d 525 (8th Cir. 1984).

${ }^{4} 578$ F. 2d 582 (5th Cir. 1978).

s391 U.S. 510 (1968).

${ }^{6} 391$ U.S. 510 , at 522, n. 21.

7408 U.S. 238 (1972).

${ }^{8} 428$ U.S. 153 (1976).

9 Thirty-eight states have rewritten capital punishment statutes sincethe Furman decision. The Georgia statute is generally the modelfor these statutes, the fundamental provisions of which are the two-stage trials and automatic appeals to the highest state 
court in all instances where capital punishment is meted out.

${ }^{10} 380$ U.S. 202 (1965).

${ }^{11}$ U.S. X7 (1967).

12396 U.S. 320 (1970).

${ }^{13} 407$ U.S. 503 (1972).

${ }^{14} 418$ U.S. 135 (1974).

15419 U.S. 522 (1975).

16489 U.S. 357 (1979).

${ }^{17} 448$ U.S. 40 (1980).

${ }^{18}$ See Robert M. Berry, "Death Qualification and the 'Fireside Induction,"5 $U$. of Arkansas at Little Rock Law Journal 1, (1982) for a further development of these categories.

${ }^{19}$ Jurow, "New Data on the Effect of a 'Death Qualified' Jury on theGuilt Determination Process," 84 Harvard Law Review 567 (1971).

${ }^{20}$ As indicated above, psychological studies indicate that any convictionwould be harder to get from persons opposed to the dealth penalty, and in any case, the very fact that defense attorneys are anxious to have those persons on the guilt-innocence phase jury is strong evidence of their predilections. See, e.g., Edward Bronson, "On the Conviction Proneness and Representativeness of the Death-Qualified Jury: An Empirical Study of Colorado Venieremen," 42 Colorado Law Review 1, (1970).

2122569 F. Supp. 1548 (E.D. Ark. 1983).

${ }^{23}$ See note 20 above.

${ }^{24}$ Ibid.

${ }^{25} 438$ P. $2 d 33$ (1968).

${ }^{26}$ See Washington v. United States 390 F. $2 d 444$ (D.C. Cir. (1967).

${ }^{27} 406$ U.S. 404 (1972).

${ }^{28} 435$ U.S. 223 (1978).

${ }^{29} 441$ U.S. 130 (1979).

${ }^{30} 261$ U.S. 86 (1923).

${ }^{31} 342$ U.S. 165 (1952).

${ }^{32}$ See Korematsu v. United States 323 U.S. 214 (1944).

${ }^{33}$ See Korematsu v. United States 323 U.S. 214 (1944).

${ }^{34}$ Eddings v. Oklahoma, No. 86-6169. 